\title{
National Saving and Population Ageing
}

\section{Ross Guest and Ian McDonald}

$\mathrm{L}$ ike most industrialised countries, Australia's population is ageing due to the progression of the baby boom generations, increasing longevity and decreasing fertility. These trends, with no further decrease in fertility, imply that the proportion of population aged over 74 years will increase from 11.6 per cent in 1999 to 15.4 per cent in 2024 and 23.2 per cent by 2051 (ABS, 1998:11). Should, as seems likely, fertility fall further from its current level then these proportions of old people will increase even further in the future. The economic impact of this ageing population is increased by the fact that old people consume relatively large amounts. According to the calculations in Guest and McDonald (2001a), for people aged over 74 years private plus public expenditures are 19 per cent higher than for other adults. High expenditures on health are the major driving force for this difference. These two factors, the ageing population and the relatively high consumption demands of the old, imply a fall in the labour force relative to the consumption demands of the population by about 12 per cent by 2051 .

In addition to this, the perennial immigration debate is being fuelled by supporters of lower immigration, such as the Premier of NSW, Bob Carr, and the One Nation Party. So Australia faces the possibility of demographic change, not just from population ageing but also from lower immigration. A decrease in immigration would tend to increase further the proportion of the aged in the total population.

What are the economic implications of such demographic changes? How will demographic change affect living standards in the future? Is the prospective demographic change faced by Australia a good reason for the introduction of government policies aimed at increasing national saving? This paper explains how our recent research can help to answer these questions.

The consensus view is that Australia is not saving enough. For example, a survey of government, private sector and academic economists, members of the Canberra branch of the Economic Society of Australia, revealed a 'high consensus support for the proposition that increasing national saving should be a major policy priority' (see Argy, 2001:3). Politicians also appear to accept the view that saving is too low. Alan Wood recently wrote '... there now seems to be bipartisan acceptance that Australia has a national savings problem' (Wood, 2001).

Three reasons can be identified for thinking that Australia has a saving problem. First, there was a downward trend in the rate of national saving from the early 1970's to the 1990's. Second, associated with this, was an increase in

Ross Guest is Senior Lecturer in Economics at Griffith University and Ian McDonald is National Australia Bank Professor of Economics at The University of Melbourne. 
Australia's net foreign liabilities. Third, as noted above, prospective demographic trends suggest a problem in the future of too many consumers and too few producers. It is argued that one way to prepare for this future is an immediate increase in the rate of national saving.

Fitzgerald $(1993 ; 1996 ; 1999)$ argued on the basis of the three reasons above - low national saving, rising net foreign liabilities and the prospective ageing of the population - that Australia would be well served by an increase in the rate of national saving of five per cent of GDP. Ablett (1996), using an intergenerational accounting model, made calculations that show that future increases in consumption per capita will lag behind productivity increases. From this, Ablett argued that Australia's current rate of national saving is inadequate to permit intergenerational balance. Cashin and McDermott (1998), on the basis of an econometric analysis of past trends in saving and the current account balance, conclude that 'the increase in net national saving required to satisfy (Australia's) external borrowing constraint is about two to four per cent of GDP'.

In this paper we use our research on the implications of prospective demographic change in Australia to assess the case for Australia to increase its current rate of saving. The distinguishing feature of our research is that it addresses explicitly the link between saving and living standards. Because of this link, one can on the basis of our research judge the desirability of a particular level of saving by considering the implications for living standards. It is the latter which are important. Living standards are the ultimate objective of economic policy - other economic objectives such as increasing the rate of saving or satisfying the external borrowing constraint are intermediate objectives whose importance depends on their impact on living standards. It will be seen that, by focusing on living standards, a different view emerges from those noted above. In particular, it appears that Australia does not have a problem of insufficient saving.

Milton Friedman (1990) points out that the optimal level of saving is the level chosen by households if their choice is undistorted. Friedman sees the government as the distorter. Loayza, Schmidt-Hebbel and Serven (2000) take a broader approach, listing the distortions that push the level of saving away from the socially optimal as externalities, market failures and policy-induced distortions. As they point out, some of these distortions lead to excessive saving (for example, the lack of risk-sharing instruments) and others to under-saving, such as insufficient government saving. A priori, the net effect of these distortions is ambiguous.

From the viewpoint of inter-generational equity there is one striking fact that suggests no problem of insufficient saving. That fact is the positive secular trend of living standards. For the last 100 years, and longer, the later generations did better than the earlier. Thus the decisions of earlier generations did not reduce the living standards of those coming after. Instead, their chosen level of saving was high enough to generate rising living standards. From the viewpoint of intergenerational equity, this suggests that the net effect of the distortions has been to cause excessive saving. 


\section{The Simulation Model}

Our simulations reported below are calculated from applying a model of optimal per capita consumption to Australia (see Guest and McDonald, 2001a). The essence of the model can be described as follows:

- In each year over a long, effectively infinite, projection period a cash flow is calculated as output less investment.

- The output component of this cash flow is produced by the employment of labour and capital, according to a production function.

- The path of employment levels over the projection period is calculated from the population projection.

- The capital stock with which the employees work grows according to investment and depreciation.

- Investment is determined optimally, in that the marginal product of investment adjusted for depreciation is equal to the real world rate of interest which is assumed fixed at six per cent. The implication of optimal investment is that the capital stock grows with employment.

- The productivity of labour and capital grows at the rate of total factor productivity. In line with the experience over the previous century, the annual rate of growth of total factor productivity is assumed to be 1 per cent.

- The cash flow of output minus investment calculated in this way is used to finance the path of consumption per capita (called living standards) over the projection period and to accumulate a level of wealth (defined as the domestic capital stock less net liabilities to overseas residents) at the end of the projection period that satisfies a terminal wealth condition. The terminal wealth condition prevents a run-down in wealth.

A given path of cash flow can finance an infinite variety of patterns of living standards. To choose between these, we impose an optimality criterion. This criterion requires the path of living standards to maximise a social welfare function. The path of living standards so chosen is smooth, in that it has a roughly constant rate of growth. This accords with the usual idea of economists that people prefer not to experience fluctuations in their living standards.

The role of saving in the model is to 'support' (i.e. finance) the path of living standards and accumulate the terminal wealth stock, given the cash flow generated by output less investment. If demographic change can be expected to be a burden in that it will threaten the level of living standards in the future then the model will calculate a large level of saving in the present so that the future burden (i.e. the reduction in living standards) is shared between those alive now and those alive in the future.

Will population ageing threaten future living standards? The model captures several mechanisms through which population ageing influences living standards. Two mechanisms tend to reduce living standards. First, a falling employment to population ratio, implied by population ageing, reduces output per capita and thus 
the per capita size of the discounted cash flow. Second, an increasing proportion of old people will reduce the consumption per capita from a given level of total consumption because of the relatively high levels of consumption per old person. This effect will also tend to reduce living standards. However, there are three other mechanisms through which ageing tends to increase living standards. First, an ageing population will yield an investment dividend because of the reduced capital requirements of a smaller workforce. This tends to increase the cash flow and so increase living standards. Second, an ageing population will yield a consumption dividend because of the reduced consumption demands from a smaller number of children. Third, an older workforce is more productive. By capturing these effects, our model calculates the net effect of demographic change on living standards.

A number of demographic scenarios are specified in Table 1. These scenarios have been chosen to illustrate the influence of the ageing that will occur with unchanged fertility and immigration and the influences of further reductions in the total fertility rate (TFR) and reductions in the net immigration rate.

Table 1: Demographic scenarios

\begin{tabular}{|l|l|}
\hline Scenario name & \multicolumn{1}{|c|}{ Description } \\
\hline Base case & TFR $=1.75 ;$ annual net immigration $=0.54 \%$ of population \\
\hline Low fertility & $\begin{array}{l}\text { TFR falls from } 1.75 \text { in } 1997 \text { to } 1.30 \text { in } 2009 ; \text { annual net } \\
\text { immigration }=0.54 \% \text { of population }\end{array}$ \\
\hline Zero immigration & TFR $=1.75$; annual net immigration $=0$ \\
\hline No ageing & $\begin{array}{l}\text { Base case population projection. Constant aggregate } \\
\text { employment to population ratio. Hence, aggregate } \\
\text { employment grows (or declines) at the same rate as total } \\
\text { population from 1997. }\end{array}$ \\
\hline
\end{tabular}

Notes: TFR is total fertility rate. The base case rate of 1.75 is close to the number observed in Australia in the last two years. The rate of TFR $=1.3$ can be thought of as the lowest likely fertility rate

Base case immigration rate of $0.54 \%$ of the population is close to the actual rate of immigration in recent decades.

In all projections, for future mortality it is assumed that life expectancy will increase by 0.4 years every 5 years

\section{Results}

\section{Living standards}

Simulating our model using the demographic scenarios in Table 1 yields the projections for optimal living standards and national saving shown in Figures 1 and 2 respectively. 
Figure 1: Projected Living Standards, Australia, 1999 to 2050

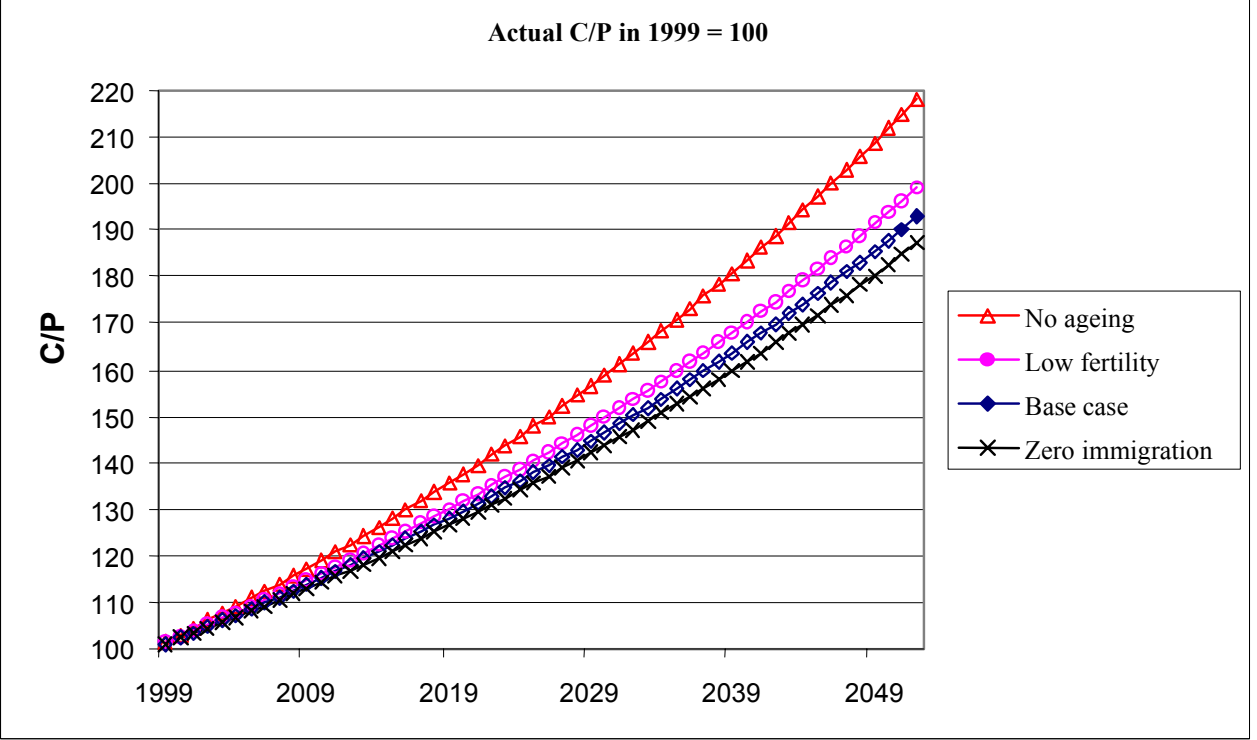

Figure 2: Projected National Saving, Australia, 1999 to 2050

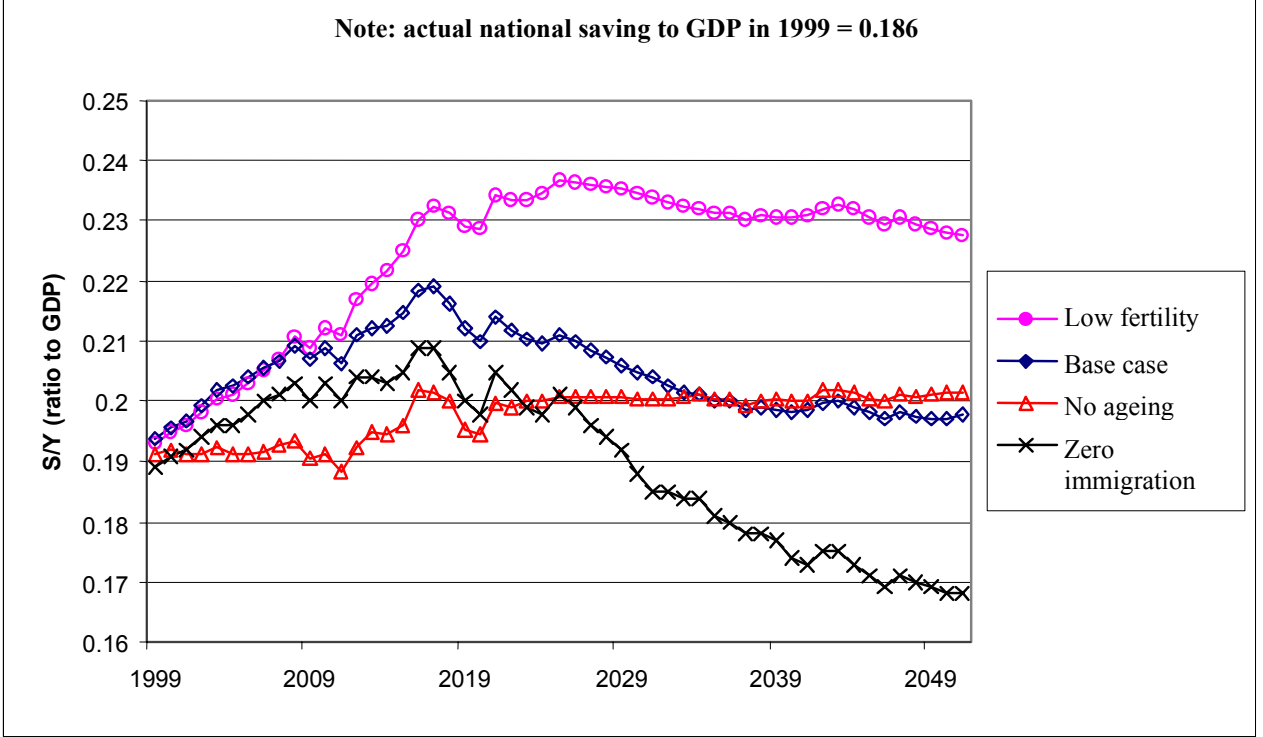

We first discuss the effects of the demographic scenarios on optimal living standards or consumption per capita $(\mathrm{C} / \mathrm{P})$.

To consider the impact on living standards of the population ageing implied by what can be called the demographic status quo in 1999 (including: the baby 
boom; a fertility rate that decreased to 1.75 by 1999 ; and a life expectancy that is expected to increase into the future), it is useful to compare the 'No ageing' and the base case simulations. For the no ageing simulation, we hold the aggregate employment to population ratio constant at its 1999 level throughout the projection period. This implies that aggregate employment grows at the same rate as aggregate population. This is faster than the rate of growth for the base case, because of the ageing effect captured in the latter. The comparison of the no ageing and the base case illustrated in Figure 1 reveals that by the year 2050, if there were no ageing then living standards would be 12.7 per cent higher than with allowing for the effects of ageing

From this comparison we see that the net effect of the five mechanisms described in the previous section is to reduce living standards. However, note that living standards still grow at the annual rate of 1.20 per cent. This implies that with ageing effects taken into account, living standards in 2050 are projected to be 85.8 per cent higher than in 1999 . So the effect of ageing, 12.7 per cent compared with 85.8 per cent, is small.

The small size of the ageing effect shows that the levels of future living standards are dominated by the projected annual rate of growth of total factor productivity, of 1 per cent. (Setting a different rate of productivity growth would change the rate of growth of living standards pro rata.) That rate of growth, and our assumption of optimal investment, implies that the annual rate of growth of output per worker is 1.43 per cent. Thus between 1999 and 2050, the rate of growth of living standards lags behind the rate of growth of labour productivity. Later, in the $21^{\text {st }}$ century, the rate of growth of the simulated path of living standards approaches the 'steady state' rate of growth of labour productivity.

To assess the effect on living standards due to the possibility that antiimmigration pressures in Australia may be successful in reducing the rate of immigration, consider the path of living standards implied by the zero immigration simulation in Figure 1. If we were to have zero immigration from 1999 onwards then optimal living standards would be 3.2 per cent lower by 2050 . This illustrates a general feature of our work, that lower immigration has a slightly negative impact on living standards. The dominance of young adults in the age distribution of immigrants is the cause of this effect. Thus immigration reduces slightly the relative size of the young and old dependent populations.

In many countries fertility has declined in recent years to astonishingly low levels. Most notable are Germany and Italy, where the total fertility rate declined to 1.3 and 1.2 respectively in the period 1995-2000. In Australia fertility has also decreased, but not, at least yet, to such low levels. In 1998 the TFR in Australia was 1.76 , a decrease from 1.9 for the 1990-1995 period. The real possibility that fertility in Australia will decrease below the current low level has led to concerns about the effect on future living standards and pressure for government policy to discourage low fertility (for more details, see Guest and McDonald, 2001b).

The impact of lower fertility on living standards is illustrated in Figure 1 by the path of living standards implied by the TFR 1.3 simulation. A total fertility rate of 1.3 can be thought of as the lowest plausible outcome for the TFR. As 
Figure 1 shows there is in fact a positive, albeit small, effect on optimal living standards from this extreme decrease in fertility. By 2050 living standards are 3.0 per cent higher with the low fertility scenario compared with the base case. This is in marked contrast to the fears of some. Two forces drive this positive effect. First is an investment dividend, or the reduced capital requirements of a more slowly growing level of employment. The second is a consumption dividend from reductions in fertility due to the smaller number of children.

In summary, the results of the simulations with respect to living standards suggest that the future annual rate of growth of living standards, whilst less than that enjoyed over the last 30 years, will be over one per cent, whatever reductions in the fertility and immigration may be. For these demographic shocks, the effect on the rate of growth of living standards is to be slightly reduced by lower immigration in the future and slightly increased by lower fertility in the future. Thus the simulation suggests that there is little risk to living standards from changes in immigration or fertility. Some have suggested that living standards may fall because of demographic shocks. For example the President of the Australian Population Institute, Albert Dennis (2000), claims that 'a substantial drop in our standard of living was inevitable unless' among other things we 'increase our fertility rate to the replacement level of 2.1 to 1 female'. Clearly, this fear is completely out of the ballpark.

\section{National saving}

The paths of future living standards shown in Figure 1 are supported by paths of optimal national saving, investment and current account balances. The paths of optimal national saving for the four projections are shown in Figure 2. Except for the no ageing case, the saving profiles underlying the projections of living standards in Figure 1 exhibit a hump shape. This is because for at least the next decade or so, the exact number of years depending on the demographic assumptions, the capacity of the economy to meet consumption demands actually rises until the baby boomers start to retire, after which it falls. The consumption smoothing of our optimality approach implies that we should take advantage of the period before the baby boomers start to retire by increasing saving. This hump in saving will enhance living standards in the future when the per capita consumption capacity of the economy falls.

In the base case it is optimal to increase the national saving rate from its current rate to peak at just under 22 per cent of GDP in 2017. This is about 3 percentage points above the 1999 rate of 18.6 per cent. Thereafter the optimal rate of national saving decreases to be 20 per cent of GDP by 2050. In the case where there is no ageing, the optimal saving rate increases to about 20 per cent of GDP by 2016 and remains unchanged for the rest of the period to 2050 .

Zero immigration is associated with a slightly smaller increase in the saving rate relative to the base case until the common peak year of 2017. Thereafter the optimal saving rate with no ageing decreases faster relative to the base case, to be 
only 17 per cent of GDP in 2050. On the other hand, low fertility implies a higher saving rate throughout the projection period.

That it would be a good idea to have a higher rate of saving before the baby boom retires, of course, is what many commentators have in mind when calling for an increase in saving to cope with the retirement of the baby boom generation. However, our simulations suggest that this increase in saving is small. Further work, to which we now turn, suggests that the case for even this increase is very weak.

Some people may question our simulations on the basis that the increase in national saving and the associated reduction in the current account deficit will not eventuate for Australia. There is a degree of pessimism in some quarters about increasing saving and reducing the current account deficit. While we would counter with the point that along our projected paths the increase in national saving does not require a reduction in living standards, it is of interest to consider what would happen if the ratio of national saving to GDP stays at its 1999 level. Would this be a problem? Is the growth in living standards in our projections totally dependent on the hump increase in national saving?

To answer these questions, we consider the impact on living standards of a failure of national saving to increase as a share of GDP above its present level, and thus a failure of the current account deficit to fall below its current level. We do this by assuming that investment is determined optimally, as in the base case above, but that the rate of national saving is constrained to be equal to the actual rate of national saving in 1999 (i.e. 18.6 per cent of GDP). This projection yields a path of living standards shown by 'constant $\mathrm{S} / \mathrm{Y}$ base' in Figure 3. As would be expected by the lower rate of saving implied by removing the hump, the initial effect is for slightly higher living standards. Indeed the constant $\mathrm{S} / \mathrm{Y}$ base projection yields higher living standards than the base case up to 2022. Thereafter the lower rate of saving exerts its negative effect. After 2022, living standards are lower if there is no hump in saving in the early part of the $20^{\text {th }}$ century.

Evaluation of the benefit of the hump in saving depends on evaluation of the two paths of living standards in Figure 3. This evaluation depends on one's value judgements. In our judgement, the increasing living standard, even if there is no hump increase in saving, implies that it is not imperative to increase national saving. If people in Australia choose not to increase saving in the hump fashion in the next decades, there is little reason for the government to adopt policies to force an increase in saving. This would be reducing the living standards of the less well off in order to benefit the living standards of the better off (i.e. people alive in the future). According to our value judgements, this would not be desirable.

In summary, the simulation results presented here project living standards to grow at significant rates from their actual 1999 level, despite population ageing. This is true even in the face of the most draconian immigration policies (i.e. no immigration) and the most extreme and persistent negative shock that is plausible to fertility (i.e. a decrease in the total fertility rate to 1.3). These paths of increasing living standards are supported by paths of national saving that show a small increase from the current rate over the next two decades and then a 
continuous decrease. Our simulations also show that living standards will grow if there is no increase in the rate of national saving and no decrease in the current account deficit. This is an optimistic message.

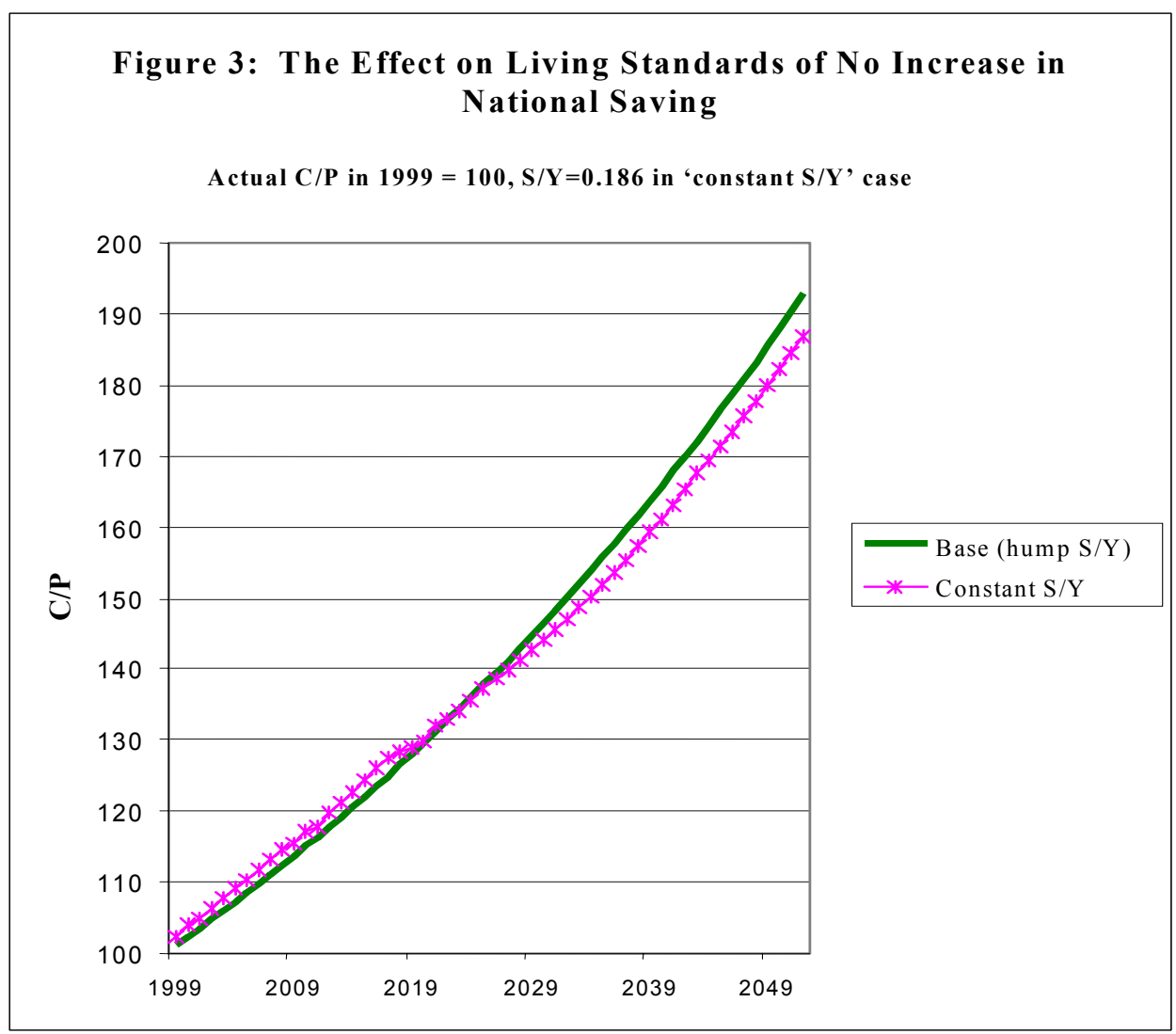

\section{Comparison with Other Studies on National Saving}

As we noted in the introduction, the consensus view appears to be that Australia should increase its rate of national saving. In this section we compare our results with previous studies that support the consensus view.

Fitzgerald has been a leading advocate of using government policy to force an increase in the rate of national saving. Fitzgerald (1996:7-8) sets out his argument concisely. He argues that to achieve a growth rate of GDP of five per cent requires a ratio of investment to GDP of 25 per cent. However to stabilise the external debt/GDP ratio to avoid, in his language, spiralling increases in external liabilities requires a current account deficit of no more than 3 per cent of GDP. Hence, using the macroeconomic accounting conditions, the ratio of saving to GDP should be at least 22 per cent. 
Even although our framework is close to Fitzgerald's, in that we make projections into the future using a macroeconomic model, we come to a different conclusion. This is partly because our simulations suggest that the optimal investment/GDP ratio is lower than the value argued for by Fitzgerald. For our base case, the optimal ratio of investment to GDP, averaged over the period 1999 to 2010 , is 22 per cent. Our optimal ratio of the current account deficit to GDP is slightly lower than Fitzgerald's, averaging 2.5 per cent for the period 1999 to 2010. These two numbers imply an optimal rate of national saving of 19.5 per cent of GDP. Our lower investment level reflects the investment dividend from reduced growth in employment due to demographic change. For our base case, the projected annual rate of growth of employment, in efficiency units, for 2000 to 2010 is 1.0 per cent, significantly less than the annual rate from 1990 to 1999 of 1.5 percent. And taking a longer period, annual employment growth is only 0.6 per cent for the period 2000 to 2050 . With lower employment growth, the optimal level of investment is lower because there are fewer new workers to equip with capital goods.

As we noted above, Fitzgerald's recommendation for increased national saving is partly due to his concern to reduce the size of the current account deficit. This concern is based on the implications for the growing size of net liabilities owed by Australian residents to foreign residents. From our simulations we can calculate the implied levels of net foreign liabilities. For our base case, these liabilities fluctuate around 60 per cent of GDP for the course of the $21^{\text {st }}$ century. Given that these projections are based on a slightly lower current account deficit than that with which Fitzgerald is comfortable, we can presume that he would be comfortable with them. Of possible concern to Fitzgerald would be our simulation in which there is no increase in national saving. The higher current account deficit in that simulation implies higher levels of net foreign liabilities in the future. The path of these liabilities is to progressively increase from 60 per cent in 1999 to 100 per cent by 2026, 135 per cent by 2100 and 155 per cent by 2150 . However, we do not interpret this path as a crisis or a spiral.

To assess the adequacy of Australia's saving rate, Cashin and McDermott (1998) look at the actual current account deficits in the past and compare these with the optimal current account deficits resulting from a consumption smoothing model. They interpret the actual deficits as sustainable if the differences between the actual and their calculation of the optimal do not grow over time. They conclude that Australia's deficits have not been sustainable and that 'the increase in net national saving required to satisfy (Australia's) external borrowing constraint is about 2 to 4 per cent of GDP'. The similarity between their approach and ours is that we also apply a consumption smoothing model in order to calculate optimal consumption, saving, investment and therefore current account balances. However, our concern is with present and future optimal values based on projections of exogenous variables from the present to the future. In particular we focus on the impact of demographic projections on optimal living standards and national saving. The Cashin and McDermott study on the other hand does not use any such projections of exogenous variables. 
Ablett (1996) extends the inter-generational accounting framework of Kotlikoff and others to include private consumption transfers. From this extension, Ablett finds that that future increases in consumption per capita will lag behind productivity increases. He concludes that 'current savings rates in Australia are inadequate to permit inter-generational balance'. The feature in common with our approach and differing from the Cashin and McDermott approach is that Ablett uses demographic projections, including migration scenarios.

In our work it is also the case that, in the future, increases in consumption per capita will lag behind productivity increases. We do not interpret this as an intergenerational imbalance at the expense of generations alive in the future because, even with this lag, future generations will be better off than current generations. Going further, our method can also shed light on what it would take to generate a rate of growth of living standards comparable to the rate of growth of labour productivity. An immediate increase in the rate of national saving to 23.3 per cent of GDP, to be followed by further increases up to a peak of 26.2 per cent of GDP by 2017 would generate such an outcome. However, the cost would be an immediate cut of 5.8 per cent in living standards, caused by the immediate increase in saving. Along this faster growth path, living standards would not catch up with the base case simulation until 2022. In our view to force the faster growth path of living standards on the Australian population would be a case of intergenerational imbalance at the expense of the currently alive population.

\section{Conclusion}

From our research reported here, we conclude that there is no case for government policies to increase national saving to deal with population ageing. At the current time, one of these policies being discussed is whether to increase the compulsory superannuation levy. Our results cast doubt on the argument that the superannuation levy should be increased in order to increase national saving. Furthermore, there is no case based on the notion of protecting future living standards for policies to increase the rate of fertility, or to slow down or stop the decrease in fertility observed in recent years. While there are important economic problems in Australia, notably the high rate of unemployment, there is no case for forcing an increase in national saving to prepare for prospective demographic change.

\section{References}

Ablett, J. (1996), 'Intergenerational Accounting and Saving in Australia', Economic Record 72(218):236-245.

Australian Bureau of Statistics (1998), 'Population Projections 1997 to 2051', Catalogue No. 3222.0, Ausinfo, Canberra. 
Argy, F. (2001), 'Economic Rationalism in Australia - Survey of Members of the Economic Society of Australia, ACT Branch', Economic Papers 20(1):1-14.

Australian Financial Review (2000), 'Tight rein on Budget a Must', Editorial, 28 February.

Cashin, P. and C. McDermott (1998), 'Are Australia's Current Account Deficits Excessive?’, Economic Record 74(227):346-61.

Dennis, A. (2000) 'Up and Running Fast', APop Vision, available at http://www.apop.com.au/news/july2000/0700_1.html.

Fitzgerald, V. (1993), National Saving: A Report to the Treasurer, AGPS, Canberra.

Fitzgerald, V. (1996), 'Public Policy and National Saving', Agenda 3(1):3-30.

Fitzgerald, V. (1999), Discussant in 'Policy Implications of the Ageing of Australia's Population', Conference Proceedings, Ausinfo, Canberra.

Guest, R. and I. McDonald (2000), 'Population Ageing and Projections of Government Social Outlays in Australia', Australian Economic Review 33(1):49-64.

Guest, R. and I. McDonald (2001a), 'Ageing, Optimal National Saving and Future Living Standards in Australia', Economic Record 77(237):117-134.

Guest, R. and I. McDonald (2001), 'Is Low Fertility a Threat to Living Standards in Australia?', available at (under 'Consumption Balance'):

http://melbecon.unimelb.edu.au/staffprofile/imcdonald/balance.html.

Hewson, J. (2000), 'Ignore It and Age Will Weary Us', Australian Financial Review, 21 January.

Loayza, N., K. Schmidt-Hebbel, and L. Serven (2000) 'Saving in Developing Countries: An Overview', World Bank Economic Review 14(3):393-414.

OECD (1996), Ageing in OECD Countries: A Critical Policy Challenge, OECD, Paris.

Stone, J. (1993), 'How to Achieve Full Employment', IPA Review, 46(2):29-34.

Wood, A. (2001), 'Raising Levy isn't a Super Idea in Election Year', The Australian, 10 April.

The authors are grateful to two anonymous referees and Graeme Wells for helpful comments. 